\title{
CADRE TRAINING ACCORDING TO HO CHI MINH IDEOLOGY: A CASE STUDY ON CADRES OF CIVIL AFFAIRS COMMITTEE OF PROVINCIAL PEOPLE'S COMMITTEES
}

\section{Yen Hai Nguyen}

\section{Article History}

Received: August 15, 2020

Accepted: September 7, 2020

Published: September 30, 2020

\author{
Keywords \\ Fostering cadres, Ho Chi \\ Minh ideology, party \\ committee, provincial \\ people's committee
}

\author{
Academy of Politics Region I, Vietnam \\ Email: nguyenhaiyen2201@gmail.com
}

\section{INTRODUCTION}

Ho Chi Minh Ideology has become a consistent principle throughout all the revolutionary periods led by the Party. Proper application of his ideology in the current renovation will meet the requirements for the country's sustainable development (Nguyen Ngoc Kha, 2015), ensuring success for the process of building and developing Vietnamese people in general and the personnel of Civil Affairs Committee of the People's Committee in provinces in particular. Civil Affairs Committee of the Provincial People's Committee is an organization established by the Provincial Standing Committee at the Provincial People's Committee to thoroughly lead and organize the implementation of the Party's policies and guidelines; create proposals for the Provincial People's Committee in terms of directions, activities, organization and staff to make decisions based on the corresponding level; lead the supervision of the compliance of the Party's disciplines and policies at the Provincial People's Committee. Personnel structure in the Civil Affairs Committee of the Provincial People's Committee includes Chairman, Vice Chairmen of the Provincial People's Committee, Director of Department of Home Affairs, and Chief of the Provincial People's Committee Office. The Chairman of the Provincial People's Committee is the Secretary of the Party Committee of the Provincial People's Committee. The Standing Vice Chairman of the Provincial People's Committee is the Deputy Secretary of the Provincial Party Committee. Accordingly, the Civil Affairs Committee of the Provincial People's Committee has a particularly critical position and role, as the Party's organization in the Provincial People's Committee established by the Provincial Standing Committee, providing direct leadership and bearing the highest responsibility towards the Standing Committee on quality and activities of the Provincial People's Committee. The issue of implementing the responsibilities of the Provincial People's Committee's cadres and committees over the past time still has had limitations. Therefore, training cadres who are members of the Civil Affairs Committee of the People's Committee according to Ho Chi Minh Ideology is an important task, which should be done seriously, regularly, scientifically and effectively. The article focuses on clarifying Ho Chi Minh' thoughts on cadres fostering as well as proposing solutions to improve the quality of training cadres who are members of the current Provincial People's Committee according to Ho Chi Minh Ideology.

\section{LITERATURE REVIEW}

Ho Chi Minh National Academy of Politics (2018) has compiled Ho Chi Minh research papers on cadres and human resource work as well as the application of his thoughts in the current period with a focus on staff training and developing high-quality human resources, emphasizing duties and responsibilities of current cadres and party members. Evaluation of the Party's staff training process has been systematically presented and clarified, in which the trainees' positions and roles, training targets and syllabus are emphasized (Academy of Politics - Administration Region I, 2012, pages 159-162).

According to Minister Nguyen Xuan Phuc (2019), among the key solutions to renovate the training process for cadres, civil servants and human resources in the public sector are: comprehensively renovating the program and 
training materials; developing a management team with innovative and pioneering mindsets; scientific management knowledge, capacity of applying modern technologies; promoting and improving the efficiency of scientific research and consultancy activities; building a contingent of qualified, professional, knowledgeable, practical, creative, ethical and political researchers and staff. Regarding the issues posed in the training and fostering of political theory at the Ho Chi Minh National Academy of Politics and current provincial and city political schools, there have been 04 groups of specific solutions to improve the training quality for leaders and managers in the political system (Truong Thi Thong, 2017). According to Olaniyan and Lucas (2008), the staff training and development is based on the premise that employees' skills are improved for the organization's overall development. Training is the systematic development of the knowledge, skills and attitudes needed by an employee to fully perform a certain task or job. Newcomers to the organization possess different skills although not all of them fulfill the its demands. Training and development sessions must be provided for employees to help them work towards the desired goals.

However, there has not been any research that mentions the current training process of cadres who are members of the Civil Affairs Committee of Provincial People's Committee according to Ho Chi Minh Ideology.

\section{RESEARCH METHODS AND RESULTS}

\subsection{Research methods}

- Theoretical research method: Document analysis on Ho Chi Minh Ideology; resolutions, documents and directives of the Party; scientific works; analysis and consolidation of the documents to clarify research questions regarding Ho Chi Minh Ideology on cadres and staff fostering; the Party's viewpoints and policies on cadres training; and issues related to the quality of the current members of the Civil Affairs Committees of Provincial People's Committees.

- Empirical research method: conducting research on the quality of the current personnel of the Civil Affairs Committee of Provincial People's Committee Party Committee, and the quality of training according to Ho Chi Minh Ideology provided for these members as described in central and local reports.

\subsection{Research results}

\subsubsection{Ho Chi Minh Ideology on cadre development}

In his time, President Ho Chi Minh always devoted a special interest to training and developing revolutionary cadres and his thoughts on cadres development has always preserved practical significance. Specifically, He always affirms the crucial position and role of cadres (Secretariat of the Party Central Committee, 2011a, p. 309): "The cadre is the foundation of all activities. Success or failure of every activity depends on the level of the cadre's competencies. That is a universal truth." Therefore, cadre training and development always received his special attention: "Training cadres is the core work of the Party." According to Ho Chi Minh Ideology, the training of cadres must ensure the following:

- Training cadres must ensure practicality: Practicality, above all, is shown in the mode of training, i.e. the characteristics of each occupation, requirements of the working position, and qualifications of staff must be regarded as a basis for implementation. According to the Secretariat of the Party Central Committee (2011c), the fostering of theories must be associated with reality: Practices without theory to guide the way shall become a blind practice. Reasoning without any practical application shall be fruitless. The colorful and ever-changing reality requires that the training content be promptly updated, supplemented and developed, which requires staff to constantly improve and study (p. 95). To ensure practicality, the purpose of the staff training must also be based on the requirements of the practice and satisfy practical demands.

- Training cadres must pay attention to subjects and objects: According to President Ho Chi Minh, in cadres training, it is necessary to identify "trainers" and "trainees". Participants in the activity must possess certain ethical standards, professional achievements and be a model of learning and fostering. "The trainers have to be the model in all aspects..." According to The Secretariat of the Party Central Committee (2011b), fostering cadres needs to acknowledge the object to ensure quality and efficiency: In terms of training, it is important to have a clear understanding of the learners in order to improve their abilities and remove their drawbacks. (p. 356).

- Training forms and methods must be regularly renovated: President Ho Chi Minh emphasized the relationship between the method and the objectives, the content, and the forms of training organization as well as the practicality of the training situation. Regarding training methods, the Secretariat of the Party Central Committee (2011b) pointed out "meticulous research takes time ... On the contrary, little time, poor level and meticulous research will be useless". As he reminded, "The essence lies in practicality and attentiveness rather than quantity" or "Focus on 
ambivalence, not ambiguity", avoiding the heavily formal, pretentious and unproductive training practices. President Ho Chi Minh also emphasized the forms of training: "Organize a course to fully utilize it. Choose teachers and learners carefully. Do not organize courses randomly", stating that organizing too many courses will not be effective as the training will be "forced", and teaching and learning activities will be like "dragonfly scratching through water" (p. 361).

- The spirit of "Learn, learn more, learn forever" of V.I. Lenin must be grasped: According to President Ho Chi Minh, as knowledge is endless and reality is constantly changing, both teachers and learners must strive towards lifelong learning; being a revolutionary cadre is to continuously learn; and learning must accompany with practice. He set the example of "Learning without boredom, teaching without exhaustion" of Confucius to talk about the spirit of learning. Lifelong learning means studying at school and in books, learning from each other and from the people, as not learning from the people is a major shortcoming.

Ho Chi Minh Ideology on staff training is very comprehensive and profound, from defining the position and the important role of staff training, to the purpose, content, methods, issues, and central topics in the process. The Communist Party of Vietnam inherits and creatively applies President Ho Chi Minh Ideology to foster cadres, specifically the training of cadres who are members of the current Provincial People's Committee, meeting the requirements and targets in each revolutionary period.

3.2.2. The current situation of training cadres who are members of the Civil Affairs Committee of the Provincial People's Committee according to Ho Chi Minh Ideology

Fully integrating with the views and thoughts of President Ho Chi Minh on staff training and fostering, over the years, the Communist Party of Vietnam has issued many resolutions related to cadre training and fostering, the most recently of which is the Resolution No. 26-NQ/TW, dated May 19, 2018, in the Seventh Conference of the XII Central Executive Committee on developing a contingent of cadres at all levels, especially at the strategic one, specifying the strategic, qualified, capable and reputable, on par with the targets competencies (Central Executive Committee, 2018). Therefore, grasping and applying his thoughts to developing cadres who are members of the Civil Affairs Committee of the Provincial People's Committee is currently the top priority to be carried out regularly, prudently, scientifically and efficiently.

Developing cadres who are members of the Civil Affairs Committee of the Provincial People's Committee is the process of changing awareness, ideology, attitudes and skills of these cadres, contributing to cultivating political bravery, revolutionary morality, proper awareness of the Party's views, guidelines, resolutions and directives on the functions and tasks of the Civil Affairs Committee of the Provincial People's Committee; and each individual's personal responsibilities and duties to perform the assigned tasks. The training is mainly to supplement and update the knowledge and information that the members of the Provincial Party Committee have already formed through their work experience. The subjects of training for members of the Provincial People's Committee's Civil Affairs Committee include the Provincial Party Committees and Provincial Standing Committees. Objects are members of the Party Committee of the Provincial People's Committee including: Chairman of the Provincial People's Committee, Vice Chairmen of the Provincial People's Committee, Director of Department of Home Affairs, and Chief of the Provincial People's Committee Office.

Over the past time, the Civil Affairs Committee of the Provincial People's Committee has actively coordinated reviewing the planning for leaders and managers assignment; advising and developing mechanisms, policies, regulations, guidance projects and plans on training cadres who are Civil Affairs Committee members. However, in reality, it can be seen that the training process is not close to the practical requirements, lacking the association with the planning, assessment and usage of staff; the training method also has had few breakthroughs to meet the requirements of the new situation.

3.2.3. Solutions to improve the training process of cadres who are members of the Provincial People's Committee's Civil Affairs Committee according to Ho Chi Minh Ideology

- Awareness and responsibility of the stakeholders about the position and role of cadres training must be raised: To improve the quality of fostering cadres who are members of the Provincial People's Committee's Civil Affairs Committee according to Ho Chi Minh Ideology, the first solution is to raise awareness and responsibility of the Provincial Party Committee, the Standing Committee of the Provincial Party Committee and other members of the Civil Affairs Committee of the Provincial People's Committee. In order to take the right action, one must have the right awareness which will lead to proper acknowledgement of responsibility and behavior. As seen in the practical 
context, if the Provincial Committee, the Standing Committee of the Provincial Party Committee and members of the Civil Affairs Committee of the Provincial People's Committee are fully aware of the importance of cadres training, the training of these cadres according to Ho Chi Minh Ideology will be carried out methodically and properly with high quality, high efficiency and vice versa. To improve the quality, first of all, it is necessary to renew the mindset and awareness of each concerned organization and individual. The correct and comprehensive awareness of the demands and objectivity of fostering cadres who are members of the Provincial People's Committee's Civil Affairs Committee according to Ho Chi Minh Ideology will create consensus and unification in actions and active participation in this process of related cadres and Party members.

- Organizing training classes for cadres must ensure practicality: Contents of the training session should cover practical issues directly related to the organization and operation of the Provincial People's Committee and the responsibilities and duties of each Civil Affairs Committee's member. Firstly, the current resolutions, regulations and guidelines of the Party related to the organization and operation of the Provincial People's Committee's Civil Affairs Committee should be included. Secondly, the contents should cover the regulations of the Standing Committee of the Provincial Party Committee on positions, roles, functions, tasks, organizational and operational principles, and the main working relationships of the Provincial People's Committee's Civil Affairs Committee. Thirdly, regulations on the responsibilities and duties of each member of the Civil Affairs Committee of the Provincial People's Committee are to be added. Fourthly, there should be consideration on the issues arising from practical context that the Party's resolutions and documents have yet specified and specifically instructed or that experiences different interpretations.

- The quality of lecturers and reporters who perform the staff fostering must be improved: The object of the cadre training class is the member of the Provincial People's Committee, including: Chairman and Vice-Chairmen of the Provincial People's Committee, , Chairman of the Provincial People's Committee, Director of Department of Home Affairs, and Chief of the Provincial People's Committee Office. They are cadres who are members of the Provincial People's Committee and leaders of an important specialized agency of the Provincial People's Committee with high professional qualifications in political theory, long working experience as well as experiences in leadership and management. Therefore, lecturers of the training class for the members of the Civil Affairs Committee of the Provincial People's Committee must possess high quality and reputation, rich practical experience, a deep understanding of the organization and operation of the personnel in the Civil Affairs Committee of the Provincial People's Committee as well as the responsibilities and duties of each member. Lecturers and trainers in these courses can be the Secretary of the Provincial Party Committee, Deputy Secretary of the Provincial Party Committee, or experts at the advisory agencies who assist the Party Central Committee with deep understanding and experiences in order to discuss and answer questions raised by members of the Civil Affairs Committee of the Provincial People's Committee. To effectively perform the task of developing cadres who are members of the Provincial People's Committee's Civil Affairs Committee, the Provincial People's Committee must call for attention to build and develop the team of trainers in these following three aspects: Having achieved training qualifications according to the prescribed standards for each faculty title; reaching the uniformity of trained majors of the faculty in accordance with the content, training programs, fostering and teaching content implementation programs; showing exemplary morality, lifestyle, scientific working style, pedagogical skills, and the continuation to research, explore and innovate teaching methods to suit the subjects and the current development practices.

- The forms and methods of fostering cadres must be continuously renovated in accordance with practical conditions: It is necessary to diversify forms of training classes for cadres who are members of the Provincial People's Committee to bring about the highest quality and effectiveness. Firstly, regarding the training at the beginning of the term, after the Provincial Standing Committee sets up the Civil Affairs Committee of the Provincial People's Committee for a new term, it is necessary to appoint members to concentrate on a longer time, and the content of the training should include all current decisions, regulations and guidelines of the Central Government related to the organization and operation of the Civil Affairs Committee of the Provincial People's Committee and the responsibilities and duties of each member. Subjects participating in the fostering course are all members of the Civil Affairs Committee of the Provincial People's Committee. Secondly, annual training for members of the Provincial People's Committee's Civil Affairs Committee may be held in a shorter time. The content of the training shall include new resolutions, documents, guidelines and regulations related to the organization and operation of the Provincial People's Committee's Civil Affairs Committee. Subjects participating in the course are all members of the Civil 
Affairs Committee of the Provincial People's Committee or members assigned by the Civil Affairs Committee of the Provincial People's Committee to be in charge of areas directly related to the resolutions, documents, new guidelines and regulations. Thirdly, additional training for members of the Provincial People's Committee cadres is provisional. This form of training is organized with a smaller scale, shorter time and more flexibility. The content of the training includes all current resolutions, regulations and guidelines of the Central Government related to the organization and operation of the Provincial People's Committee's staff committee and the responsibilities and duties of each member. In particular, it is necessary to emphasize the Party's resolutions, regulations and guidelines related to the functions, tasks and areas of responsibility of the newly appointed members of the Civil Affairs Committee of the Provincial People's Committee. Methods of training cadres who are members of the Provincial People's Committee's Civil Affairs Committee should be diversified, flexible, and combined from many different methods. For the content to thoroughly grasp and exchange current resolutions, regulations and guidelines of the Party relating to the organization and operation of the Provincial People's Committee's staff committee, the main method is to present and organize questions-and-answers sessions. For the contents related to the issues that arise in the practical activities of the provincial People's Committee's staff committee, the main method can be team assignment through giving case-handling exercises related to the mistakes which are often made in the activities of the Provincial People's Committee's staff to improve skills and knowledge from the practical experiences of professional success and failure.

- The sense of example should be raised and the members' continuous learning efforts should be recognized: Each member of the Provincial People's Committee must actively study and conduct research to grasp the Party's viewpoints, pathway, policies and laws of the State; foster and practice their own morality, especially the Party's character. At the same time, each cadre must regularly update new knowledge and experiences of other Provincial People's Committees' Civil Affairs Committees to train and strive to improve the professional level, political bravery, and absolute loyalty to the Party; raise a sense of responsibility; promote capacity; take initiative and creativity in performing tasks. Regularly study and follow Ho Chi Minh Ideology, morality and working ethics; actively fight against and prevent the issues of degrading manifestations of political ideas, morals, lifestyles, "selfdevelopment", "self-transformation"; and not violate the Party members' obligations, the Party's regulations, and the laws of the State.

- The quality of inspection and supervision should be strengthened; preliminary and summary review of the cadre fostering progress should be held regularly: It is necessary to inspect, monitor, evaluate, objectively and transparently generalize the quality and effectiveness of training classes for cadres who are members of the Civil Affairs Committee of the Provincial People's Committee. It is necessary to recognize the importance of preliminary and summary review of lessons learned after the completion of each training class for cadres who are members of the Civil Affairs Committee of the Provincial People's Committee. On that basis, lesson could be drawn to promote strengths, promptly detect limitations and weaknesses, clearly point out the responsibilities of each relevant individual for timely adjustment, supplementation, remedy and handling.

\section{DISCUSSION AND CONCLUSION}

Currently, our Party is creatively applying Ho Chi Minh Ideology on cadres in general and on cadres fostering in particular in response to changes in the new period. This is also an important measure to create a favorable environment for the work of training cadres who are current members of the Civil Affairs Committee of the Provincial People's Committee to achieve practical results. Through research as well as the practical situation of localities, it is clear that if the focus is on developing the members of the Civil Affairs Committee of the Provincial People's Committee according to Ho Chi Minh Ideology, the quality and efficiency of the organization will be enhanced as the members will perform their assigned tasks better. In contrast, if the Provincial People's Committee conducts the training in a heavily formal, pretentious and unproductive manner, the members will not be fully aware of their responsibilities and tasks and so suffer from many limitations and shortcomings. In the practical context, even a number of members of the Civil Affairs Committee of the Provincial People's Committee have been subjected to the Party's disciplinary measures and even criminal prosecution by law. Therefore, regular, serious and effective training of members in the Civil Affairs Committee of the Provincial People's Committee following Ho Chi Minh Ideology will make an important contribution to improving the quality of the organization and operation of the executive Civil Affairs Committee of the Provincial People's Committee, leading to successful fulfillment of the local political targets. 


\section{REFERENCES}

Academy of Politics - Administration Region I (2012). Organization Work. Politics - Administration Publishing House.

Central Executive Committee (2018). Resolution No. 26-NQ/TW dated May 19, 2018 on Developing a contingent of cadres at all levels, especially at strategic level, with sufficient qualities, capabilities and prestige, on par with mission competency.

Ho Chi Minh National Academy of Politics (2018). Ho Chi Minh Ideology on the cadres and the cadre work. National Political Publishing House.

Nguyen Ngoc Kha (2015). Ho Chinh Minh Thoughts on new well-rounded Vietnamese people: the development of contemporary Vietnamese people. Journal of Science, Ho Chi Minh City Pedagogical University, 4, 81-89.

Nguyen Xuan Phuc (2019). Training cadres, civil servants and human resources for the public sector: The demand for more drastic and profound innovation. State Management Journal, 281, 5-9.

Olaniyan, D.A., Lucas, B.Ojo. (2008). Staff Training and Development: A Vital Tool for Organisational Effectiveness. European Journal of Scientific Research, 24(3), 326-331.

Secretariat of the Party Central Committee (2011a). Ho Chi Minh Complete Collection (Book 8). National Political Publishing House.

Secretariat of the Party Central Committee (2011b). Ho Chi Minh Complete Collection (Book 10). National Political Publishing House.

Secretariat of the Party Central Committee (2011c). Ho Chi Minh Complete Collection (Book 15). National Political Publishing House.

Secretariat of the Party Central Committee (2011d). Ho Chi Minh Complete Collection (Book 3). National Political Publishing House.

Secretariat of the Party Central Committee (2011e). Ho Chi Minh Complete Collection (Book 4). National Political Publishing House.

Secretariat of the Party Central Committee (2011f). Ho Chi Minh Complete Collection (Book 5). National Political Publishing House.

Secretariat of the Party Central Committee (2011g). Ho Chi Minh Complete Collection (Book 6). National Political Publishing House.

Truong Thi Thong (2017). Improving the quality of political theory training and fostering at Ho Chi Minh National Academy of Politics. Journal of Political Theory, 11, 9-16. 